\title{
Penentuan profil kromatografi lapis tipis teh daun senggani (Melastoma malabathricum L.)
}

\author{
Muhammad Taufiq Hidayah ${ }^{1, *}$, Pratiwi Apridamayanti ${ }^{1}$, Rafika Sari ${ }^{1}$ \\ ${ }^{I}$ Program Studi Farmasi, Fakultas Kedokteran Universitas Tanjungpura, Kalimantan Barat, Indonesia \\ * Korespondensi: hidayahhtaufik12@gmail.com
}

\begin{abstract}
Abstrak
Latar belakang: Teh daun senggani (Melastoma malabathricum L.) merupakan produk minuman yang dibuat dengan cara diseduh dan dibiarkan selama 15 menit, lalu diaduk sampai larut. Daun senggani menghasilkan zat yang meliputi mineral, vitamin serta asam organik yaitu asam asetat yang berfungsi sebagai tameng dari serangan bakteri patogen. Daun senggani memiliki kandungan senyawa kimia flavonoid yang berfungsi sebagai antioksidan. Penelitian ini bertujuan untuk mengetahui profil kandungan metabolit sekunder teh daun senggani menggunakan kromatografi lapis tipis (KLT) dengan perbandingan eluen air : asam asetat : butanol (A:A:B) sebagai eluen. Metode: KLT menggunakan bercak yang diperiksa di bawah sinar UV pada panjang gelombang $245 \mathrm{~nm}$ dan $366 \mathrm{~nm}$ lalu diamati secara visual kemudian bercak disemprot menggunakan pereaksi $\mathrm{AlCl}_{3}$ dan $\mathrm{FeCl}_{3}$. Hasil: Penelitian teh daun senggani diperoleh bercak senyawa flavonoid berwarna kuning dan bercak senyawa fenol berwarna hitam. Kesimpulan: Penelitian yang dilakukan dengan metode KLT menunjukkan bawa teh daun senggani mengandung senyawa flavonoid dan fenol.
\end{abstract}

Kata kunci: teh, daun senggani, KLT, flavonoid, fenol

\section{Determination of Thin-layer chromatographic profile of senggani (Melastoma malabathricum L.) leaf tea}

\begin{abstract}
Background: Senggani (Melastoma malabathricum L.) leaf tea is a traditional beverage made by brewing and allowed to stand for 15 minutes then stirring until dissolved. Substances produced from senggani leaves include vitamins, minerals and organic acids such as acetic acid which is a stronghold from pathogen bacteria. Senggani leaves contain flavonoid, a chemical compounds that has function as antioxidants. This study aims to determine the profile of secondary metabolite content of senggani leaf tea by thin layer chromatography (TLC) use with ratio water: acetic acid: butanol (A: A: B) as eluent. Methods: TLC used spots which were visually observed under UV light at $245 \mathrm{~nm}$ and $366 \mathrm{~nm}$. The spots were then sprayed with $\mathrm{AlCl}_{3}$ and $\mathrm{FeCl}_{3}$ reagents. Results: The study showed yellow flavonoid compounds and black phenol compounds. Conclusions. Thin-layer chromatograpy shows that senggani leaf tea contains flavonoids and phenols.
\end{abstract}

Keywords: tea, senggani leaf, TLC, flavonoid, phenol

\section{Pendahuluan}

Indonesia banyak terdapat tanaman yang bermanfaat untuk kesehatan tubuh manusia sehingga dapat dimanfaatkan sebagai minuman fungsional dan sebagai pengganti teh. ${ }^{1}$ Salah satu tumbuhan yang berkhasiat secara empiris di masyarakat yakni tumbuhan senggani. ${ }^{2,3}$ Tumbuhan senggani memiliki khasiat diantaranya untuk diare, sariawan, hepatitis, dispepsi, leukorea, busung air maupun bisul. Bagian tumbuhan yang dapat dimanfaatkan sebagai pengobatan adalah daun, akar, buah, dan biji. ${ }^{2}$

Tumbuhan senggani dilaporkan memiliki aktivitas antioksidan yang diperoleh dari kandungan fenol, kaemferol, hiperin, kuersetin dan kuersitrin sebagai penangkap radikal bebas. ${ }^{4}$ Penelitian tentang ekstrak air teh daun senggani menunjukkan persen penghambatan terhadap DPPH sebesar 90\% dengan waktu pencelupan 1 menit, sehingga daun senggani berpotensi sebagai bahan teh herbal yang memiliki 
aktivitas antioksidan dan antibakteri. ${ }^{5}$

\section{Metode}

Alat yang digunakan pada penelitian ini adalah alat-alat gelas (Iwaki Pyrex), blender, chamber, Lampu UV 254 dan 366 nm, oven, plat KLT Silika Gel $\mathrm{GF}_{254}$, pipa kapiler, timbangan analitik (Ohaus), dan waterbath. Bahan yang digunakan pada penelitian ini adalah asam asetat teknis, $\mathrm{AlCl} 3$ teknis, aquadest, etanol p.a, $\mathrm{FeCl}_{3}$ teknis, n-butanol teknis, dan simplisia daun senggani.

Sampel daun senggani diambil dari jalan Parit Haji Husin 2, Komplek Permata Paris, Kecamatan Pontianak Selatan, Kota Pontianak, Kalimantan Barat.

Tanaman senggani dibersihkan dan dipisahkan antara daun dan ranting, kemudian dicuci dengan air mengalir. Daun diangin-anginkan di dalam ruangan hingga kering atau bisa juga dijemur dengan ditutup kain hitam di bawah sinar matahari. Sampel daun senggani dan gaharu dikeringkan dengan oven pada suhu $50^{\circ} \mathrm{C}$. Simplisia daun senggani diblender untuk membuat serbuk kasar, lalu disimpan dalam wadah kaca bertutup.

Teh daun senggani dibuat sebanyak $50 \mathrm{ml}$ dengan konsentrasi 1,2\%, kemudian ditimbang 0,6 gram simplisia senggani lalu dimasukkan ke wadah berbeda dan dibiarkan seduhan simplisia mengambang selama 15 menit. Setelah itu, teh hasil rebusan disaring dan diaduk sampai larut. ${ }^{6}$ Teh daun senggani yang telah diseduh lalu ditempatkan pada botol kaca bening. Ditunggu hingga hasil seduhan teh mencapai suhu ruangan $\left(25-30{ }^{\circ} \mathrm{C}\right)$.

Identifikasi dengan KLT dilakukan menggunakan plat silika gel $\mathrm{GF}_{254}$, yang berukuran $1 \times 8 \mathrm{~cm}^{2}$. Teh daun senggani di totolkan pada plat silika dengan jarak $\pm 1 \mathrm{~cm}$ dari tepi bawah plat dengan pipa kapiler lalu dikeringkan dan dielusi dengan masing-masing fase gerak golongan senyawanya. $^{7}$

Plat didiamkan didalam chamber yang telah dijenuhkan terlebih dahulu dengan fase gerak yaitu air: asam asetat: butanol dengan perbandingan $5: 1$ : 1. Setelah fase gerak mencapai kira-kira tinggi mencapai $7,5 \mathrm{~cm}$, plat diambil dari chamber lalu dikeringkan di udara kemudian bercak dilihat di bawah sinar UV 254 dan UV $366 \mathrm{~nm}$. Selanjutnya plat disemprot dengan pereaksi $\mathrm{AlCl}_{3} 5 \%$ untuk golongan senyawa flavonoid, dan menggunakan pereaksi $\mathrm{FeCl}_{3}$ untuk golongan senyawa fenolik. ${ }^{7}$

\section{Hasil}

\section{Pengambilan dan pengolahan sampel}

Pengambilan daun senggani diambil sebanyak 582 gram. Kemudian daun senggani yang diambil merupakan daun yang telah dipilih dari pohonnya secara langsung dengan kondisi berwarna hijau dan di waktu pagi hari. Proses pemilihan daun merupakan proses yang penting untuk dilakukan. Hal ini terkait agar kondisi sampel yang diambil dapat digunakan untuk penelitian dan daun tersebut diharapkan memiliki metabolit sekunder yang maksimal sehingga memiliki aktivitas yang baik. ${ }^{8}$

Daun senggani yang telah didapat kemudian diolah menjadi simplisia dengan cara dikeringkan dengan oven hingga warna kecoklatan. Setelah itu di blender daun senggani hingga halus agar dapat meningkatkan luas permukaan karena ketika terjadi kontak antara larutan penyari dengan simplisa daun senggani. Simplisia daun senggani dibuat kering sehingga akan lebih awet, serta metabolit sekunder yang terkandung dalam daun senggani dan daun gaharu dapat digunakan secara maksimal.

\section{Hasil teh daun senggani}

Teh daun senggani dibuat dengan konsentrasi 1,2\% dalam $50 \mathrm{ml}$. Kemudian diseduh simplisia daun senggani. Penyeduhan dilakukan karena pada umumnya pembuatan teh dilakukan dengan cara diseduh dengan air panas. Proses penyeduhan juga dilakukan agar metabolit sekunder yang terdapat dalam daun senggani dapat larut kedalam aquadest. Keuntungan metode ini yaitu mudah untuk dilakukan, alat yang digunakan sederhana, mudah diaplikasikan dan murah. Kelemahan metode ini yaitu hasil sari yang didapat mudah ditumbuhi jamur atau kapang. ${ }^{9}$

Penyeduhan dilakukan dengan cara menimbang terlebih dahulu simplisia daun senggani 0,6 gram kemudian dipanaskan aquadest hingga mendidih. Aquadest yang sudah mendidih diambil sebanyak 50 ml menggunakan gelas ukur kemudian dituang ke dalam wadah kaca bening. Wadah kaca yang telah berisi aquadest panas tersebut kemudian dimasukkan simplisia daun senggani dan gaharu yang telah ditimbang lalu diaduk dan didiamkan selama 15 menit. Proses pengadukan dilakukan untuk mempercepat proses penyarian. Teh daun senggani yang telah didiamkan selama 15 menit kemudian 
disaring ke dalam 2 wadah botol kaca bening dengan kertas saring untuk memisahkan ampasnya. Setelah teh daun senggani disaring di dalam wadah botol kaca bening, kemudian dihomogenkan. Setelah dihomogenkan, teh daun senggani dipindahkan ke dalam wadah botol kaca gelap.

\section{Pembahasan}

KLT ialah suatu metode pemisahan senyawa berdasarkan perbedaan distribusi dua fase yaitu fase gerak dan fase diam. Analisis KLT dapat dilakukan pada ekstrak n-heksan daun senggani untuk mengetahui gambaran kandungan kimia yang terdapat dari ektrak tersebut berdasarkan kromatogram yang khas. ${ }^{10}$ Eluen yang digunakan fase gerak adalah ABB yang bersifat polar karena mengandung air. Sedangkan fase diam yang digunakan adalah plat silika gel $\mathrm{GF}_{254}$ yang bersifat polar. Kepolaran fase gerak dan fase diam mendekati sama, tetapi lebih polar fase gerak disbanding fase diam sehingga senyawa flavonoid yang dipisahkan terangkat mengikuti jalannya eluen, karena senyawa flavonoid umumnya bersifat polar. Eluen yang digunakan sebanyak $10 \mathrm{ml}$ dengan perbandingan air : asam asetat : buanol (AAB)

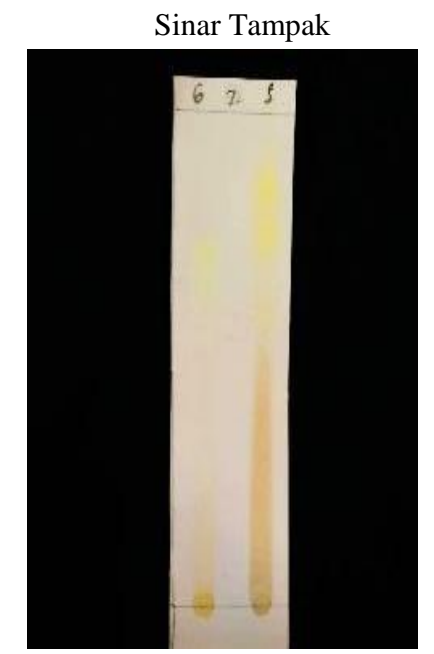

Gambar 1. Plat KLT A setelah disemprot $\mathrm{AlCl}_{3}(\mathrm{~A})$
(4:1:5) yang dapat memberikan pemisahan terbaik. Karena dari hasil komposisinya, eluen AAB bersifat sangat polar sehingga bisa memisahkan senyawa flavonoid yang juga bersifat sangat polar. ${ }^{11}$

Gambar 1 menunjukkan pada noda bercak terdapat senyawa flavonoid yang ditandai warna kuning setelah penambahan $\mathrm{AlCl}_{3}$ sehingga dapat membentuk gugus ortohidroksi kompleks tidak tahan asam pada flavonoid sehingga menyebabkan terjadi pergeseran panjang gelombang kearah visibel yang ditandai dengan noda bercak tersebut menghasilkan warna yang lebih kuning. ${ }^{12}$ Nilai Rf daun senggani $=0,9$.

Gambar 2 menunjukkan pada noda bercak daun senggani terdapat senyawa fenolik yang ditandai warna hitam kuat. Kandungan fenol positif dapat dibuktikan ketika noda bercak menunjukkan warna hitam, biru, hijau, dan merah. ${ }^{12}$ Senyawa fenol dapat diukur menggunakan senyawa asam galat yang digunakan sebagai larutan standar karena asam galat merupakan salah satu fenol stabil dan alami juga dengan harga relatif murah dibanding yang lainnya, asam galat juga termasuk dalam turunan asam hidroksibenzoat yang tergolong fenol sederhana sehingga dapat digunakan sebagai standar ketersediaan substansi yang murni dan stabil. ${ }^{12}$

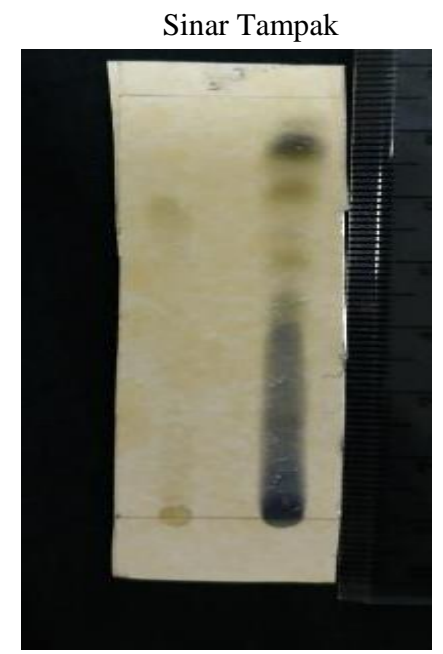

Gambar 2. Plat KLT B setelah disemprot $\mathrm{FeCl}_{3}$ (B) 


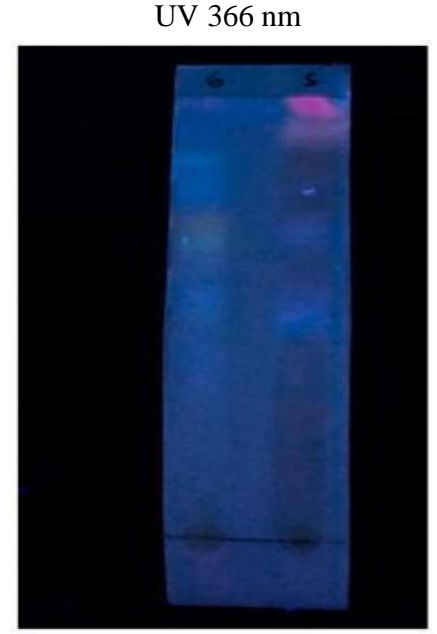

Gambar 3. Plat KLT C setelah disemprot $\mathrm{AlCl}_{3}(\mathrm{C})$

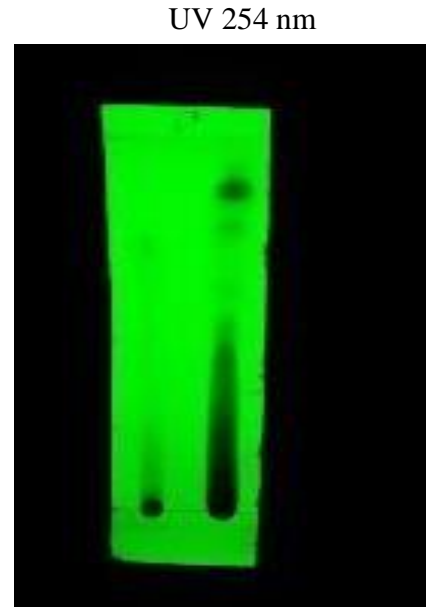

Gambar 5. Plat KLT E sebelum di semprot $\mathrm{AlCl}_{3}$ (E) Fase Gerak : Air : Asam asetat : Butanol $(5: 1: 4)$ Fase Diam : Plat silika $\mathrm{GF}_{25}$

\section{Kesimpulan}

Berdasarkan hasil penelitian profil kromatografi daun senggani di atas dapat disimpulkan bahwa teh daun senggani mengandung senyawa flavonoid dan fenol.

\section{Daftar Pustaka}

1. Wistiana, D Zubaidah E. Karakteristik kimiawi dan mikrobiologis kombucha dari berbagai daun tinggi fenol selama fermentasi. J Pangan dan Agro Ind. 2015;3(4):1446-57.

2. Dalimartha S. Atlas tumbuhan obat Indonesia jilid 2. Jakarta: Trubus Agriwidya; 2007.

3. Sulistyo AS TM. Pengembangan teknologi produksi gaharu berbasis pemberdayaan masyarakat sekitar hutan. Bogor: Pusat Penelitian dan Pengembangan Hutan dan Konservasi Alam; 2010.

4. Joffry, SM, Yon, NJ, Rofiee, MS, Meor, Mohd. MMD, Affandi, Suhaili Z et al. Melastoma malabathricum (L.)

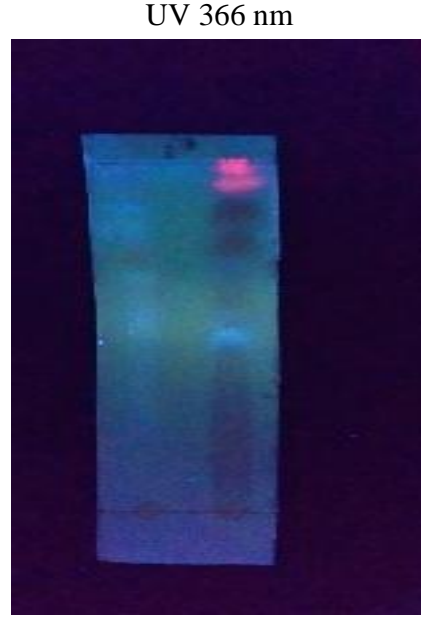

Gambar 4. Plat KLT D sebelum di semprot $\mathrm{FeCl}_{3}$ (D)

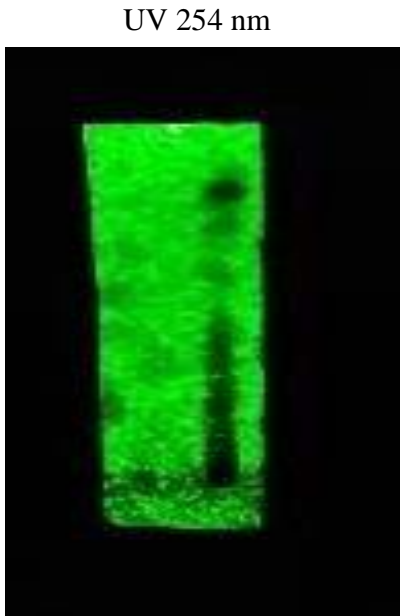

Gambar 6. Plat KLT F setelah di semprot $\mathrm{FeCl}_{3}(\mathrm{~F})$

Smith ethnomedicinal uses, chemical constituents, and pharmacological properties: a review. Evidence-Based Complement Altern Med. 2012;2011:1-49.

5. Sari, NM, Kuspradini, H, Amirta, R, Kusuma I. Antioxidant activity of an invasive plant, Melastoma malabathricum and its potential as herbal tea product. Series: Ea. Iop Publishing; 2018. 1-7 p.

6. Naland $H$. Kombucha teh dengan seribu khasiat. Jakarta: Agro Media Pustaka; 2008.

7. Harmita. Analisis fitokimia: kromatografi. Jakarta: Penerbit EGC; 2014. 190 p.

8. Departemen Kesehatan Republik Indonesia. Parameter standar umum ekstrak tumbuhan obat. Jakarta: Departemen Kesehatan Republik Indonesia; 2000.

9. Ratnani, RD, Hartati, I, Anas, Y, Endah, PD, Khilyati D. standarisasi spesifik dan non spesifik ekstraksi hidrotropi andrographolid dari sambiloto (Andrographis paniculata). Semin Nas Peluang Herb Sebagai Altern Med. 2015;147-55.

10. Rheda A. Flavonoid: Struktur, sifat antioksidan dan perannya dalam sintesis biologi. $\mathrm{J}$ belian. 2010;9(2):196-202.

11. Koirewoa, YA, Fatmawati, Wiyono I. Isolasi dan identifikasi senyawa flavonoid dalam daun beluntas 
(Pluchea Indica L.). Manado: FMIPA UNSRAT.

12. Ahmad, AR, Juwita, Ratulangi, SAD, Malik A. Penetapan kadar fenolik dan flavonoid total ekstrak metanol buah dan daun patikala (Etlingera elatior (Jack) R.M.SM). Pharm Sci Res. 2015;2(1):1-10. 